Biografistyka Pedagogiczna

Rok 4 (2019) $\mathrm{nr} 1$

ISSN 2543-6112; e-ISSN 2543-7399

DOI: $10.36578 /$ BP.2O19.04.22

Małgorzata Kutyła*

\title{
Znaczenie miejsca rekonstruowane z perspektywy doświadczeń biograficznych
}

\section{The Meaning of Place Reconstructed from the Perspective of Biographical Experiences}

\begin{abstract}
The aim of the article is to show the meaning of place in narrators' life. The basis of the analysis is the narration which I heard when carrying out biographical research among of the residents of Machów. In the early 1950s, sulphur was discovered in this area and the decision was made to build a mine. As a consequence, the residents of Machów were resettled. I carried out research with the resettled persons based on a narrative interview. My narrator moved out of Machów together with his parents and siblings in 1960. He currently works as a missionary in Madagascar.
\end{abstract}

Key words: place, biographical research, narration, local community.

* Małgorzata Kutyła (ORCID 0ooo-ooo2-5515-6374) - doktor nauk społecznych, adiunkt w Akademii Ignatianum w Krakowie, kontakt: malgorzata.kutyla@ignatianum.edu.pl. 
„[...] znakiem szczególnym jak to kiedyś po wioskach była kuźnia, [...] bo przecież mój dziadek był znanym i cenionym kowalem, mój ojciec też... a ja na swój sposób też jestem kowalem swego życia, jestem synem kowala stąd też ta podkowa, która wisi na drzwiach mego mieszkania na Madagaskarze mi o tym przypomina"1

Miejsce zawsze łączy się z konkretnym człowiekiem, dlatego też nie stanowi tylko wyodrębnionego obszaru geograficznego w przestrzeni, lecz wiąże ze sobą ludzi w ich codziennej egzystencji. Ta kreacja życia jednostki w określonym miejscu staje się możliwa poprzez dialog z przestrzenią i jej mieszkańcami. Do wyodrębnienia miejsca w przestrzeni dochodzi w konsekwencji otwarcia się na innych ludzi². Walory miejsca w życiu jednostek akcentuje Maria Mendel. Stwierdza ona, że miejsca „[...] nacechowują zmiany i odpowiadając na każdą życiową aktywność człowieka, stwarzają go zupełnie tak, jak on tworzy je w wyniku swoich nieustannych ingerencji i mniej lub bardziej spektakularnych przekształceń. Można powiedzieć, że miejsca odnoszą się do nas ze wzajemnością" ${ }^{3}$.Zatem miejsce identyfikuje jednostkę, stwarza poczucie biograficznej przynależności, „uobecniając” jednocześnie statusy, normy, wzorce postępowania. W relacji jednostka-miejsce dochodzi do współistnienia i współformowania. Gloria Ladson-Billings, zwraca uwagę na fakt, iż „nasze odczucie siebie, nasza tożsamość, jest konstruowana w relacji do miejsca, które uznaliśmy za nasz dom"4. Miejsce jest zawsze wyposażone w sens, jest kategoryczną afirmacją ludzkiego życia. Doświadczenie miejsca stanowi niejako pomost scalający jednostkę ze światem. Istota tej syntezy zawiera się w akcie wydobywania ważnych wartości, cech, umiejętności, które jednostka lokalizuje w innych miejscach na mapie swojego życia.

1 Cytat pochodzący z wywiadu narracyjnego.

2 M. S. Szczepański, W. Ślęzak-Tazbir, Niegościnne przestrzenie. Getta społeczne i przestrzenne w starym regionie przemysłowym, w: Percepcja wspótczesnej przestrzeni miejskiej, red. M. Madurowicz, Warszawa 2007, s. 95.

3 M. Mendel, Pedagogika miejsca i animacja na miejsce wrażliwa, w: Pedagogika miejsca, red. M. Mendel, Wrocław 2006, s. 10.

4 G. Ladson-Billings, Foreword, The Foreign Self. True Telling as Educational Inquiry, red. F. Tochon, Madison 2002, s. 6. 
Celem artykułu jest ukazanie znaczenia miejsca w życiu narratora. Podstawę analizy stanowi narracja, jakiej wysłuchałam w związku z prowadzeniem badań biograficznych wśród mieszkańców Machowa. Mój narrator dzieciństwo spędził w Machowie, wiosce, na terenie której w latach pięćdziesiątych ubiegłego stulecia odkryto złoża siarki. Konsekwencją prowadzonych prac geologicznych stało się przesiedlenie ludności. Zaistniałe wydarzenie w brutalny sposób zniszczyło więź i kapitał społeczny jej mieszkańców. Narrator wraz rodzicami i rodzeństwem opuścił Machów w 1960 r. Obecnie pracuje jako misjonarz na Madagaskarze. Mimo iż od ówczesnych wydarzeń minęło ponad pół wieku, tę nieistniejącą dzisiaj wioskę nazywa „moją Ojczyzną przede wszystkim od urodzenia, do której zawsze wracam pamięcią, wyobraźnią, wspominam, przypominam sobie, ojczyzna to moja ojczyzna". Z perspektywy lat nadal odczuwa emocjonalną więź z miejscem swojego pochodzenia. W istocie była mu ona najbliższą, w jakimś stopniu zamkniętą przestrzenią, w której toczyło się życie jego, rodziny, sąsiadów, miejscem oswojonym, bezpiecznym. Machów stał się źródłem samoidentyfikacji i jednocześnie fundamentem konstruowania własnej tożsamości, która jak stwierdza Henri Tajfel, jest kreowana poprzez przynależność do określonych grup społecznych, wraz z jej emocjonalnym i wartościującym znaczeniem ${ }^{5}$.

\section{Machów}

Społeczność lokalna to specyficzny typ wspólnoty. Stanowi przestrzeń psychofizyczną, którą z jednej strony kształtują jednostki i ich związki intelektualne i emocjonalne z najbliższym otoczeniem, z drugiej zaś jest obszarem działań praktycznych w określonym środowisku ${ }^{6}$. Dla narratora nie stanowi ona tylko obszaru geograficznego. Scala ją z kulturą, przeszłością, przyrodą. Machów był cenną wartością w życiu narratora, „miejscem źródłowej orientacji"7. Identyfikuje go przede wszystkim poprzez więzi społeczne, które z jednej strony współuzależniają jednostki, z drugiej zaś stanowią fundament istniejącej wspólnoty. Sposób, w jaki narrator opisuje miejsce pochodzenia, wpisuje się

5 M. Melchior, Społeczna tożsamość jednostki, Warszawa 1990, s. 44.

6 W. Theiss, Mała ojczyzna. Kultura, Edukacja, Rozwój lokalny, Warszawa 2001, s. 11.

7 P. Ricoeur, Egzystencja i hermeneutyka: rozprawy o metodzie, Warszawa 1975. 
w Tonniesowską koncepcję wspólnoty (Gemeinschaft) ${ }^{8}$. W tego typu społeczności dobro wspólnoty stanowiło prymat nad dobrem indywidualnym jednostki. Znaczenie miejsca było warunkowane zarówno wspólnymi normami, jak i homogenicznością grupy. Te elementy w konsekwencji gwarantowały wysoki stopień kontroli społecznej regulujący zachowania poszczególnych jednostek, częściej prowadząc ku harmonijnemu współżyciu społecznemu, aniżeli konfliktom. Poczucie świadomości miejsca ma charakter wieloaspektowy, gdyż jest związane z jego osobistymi odczuciami, wrażeniami, a także innymi ludźmi, którzy wspólnie użytkowali tę przestrzeń. Machów jest znaczącym miejscem w biografii narratora, gdyż w nim dokonywał się proces jego socjalizacji w grupach pierwotnych.

Wartościowanie tej przestrzeni odnosi się do relacji międzyludzkich, wspólnotowego działania, miejsc symbolicznych, które kreują pamięć o przeszłości. W 1960 r., w chwili przesiedlenia z Machowa wskutek odkrycia złóż siarkowych, narrator rozpoczynał edukację w szkole podstawowej. Do chwili obecnej potrafi określić strukturę wsi, jak sam wspomina „jakby to było na filmie", miejsca, ludzi (nazwiska), ulice, na których mieszkali machowiacy. Kreśli obraz wioski rolniczej zlokalizowanej na „pagórkowatej” przestrzeni. Życie codzienne machowiaków, jak wspomina, cechowała przede wszystkim aktywność związana z uprawą ziemi. Nie dostrzega istotnych cech, które odróżniałyby tę miejscowość od innych galicyjskich wiosek. Charakteryzowała ją homogeniczność, konieczność liczenia z pomocą sąsiedzką oraz wysoki stopień respektowania obowiązujących norm społecznych. Ze względu na niską mobilność pojawienie się „innych”, „obcych” wzbudzało sensację. W swojej narracji powołuje się na pobyt dwóch obcokrajowców. Jak wspomina: „ludzie nigdy nie widzieli czarnego człowieka, więc wszyscy gonili nawet starsze kobiety, żeby dotknąć, żeby zobaczyć”. Wskazuje również, iż „codzienność” przejawiała się w kategoriach

8 Koncepcja wspólnoty (Gemeinschaft) i stowarzyszenia (Gesellschaft) dotyczy jakościowej różnicy między społeczeństwem tradycyjnym a nowoczesnym. Pojęcie wspólnoty odnosiło się do pewnego katalogu wartości, które występują i są niezbędne w każdym społeczeństwie, oraz mogą być jakoś odtwarzane w sytuacjach swego przejściowego kryzysu. Kategorie „wspólnoty” i „stowarzyszenia” były przede wszystkim wykorzystywane przez Tonniesa do badań w zakresie zmian, jakim ulegała więź społeczna w procesie modernizacji. Por. J. Szacki, Tonnies Ferdynand, w: Encyklopedia socjologii, Warszawa 2002, s. 247; tenże, Historia myśli socjologicznej, Warszawa 2012, s. 244-245. 
pewnego spokoju, sielankowości. Wyjątkiem było uczestnictwo machowiaków w organizowanych na wsi festynach. Jak wspomina "wieś spokojna raczej była, no może oprócz tych dawnych festynów, [...] od czasu do czasu jak za dużo wypili, to może się pobili". Miejsce swojego pochodzenia określa również mianem „pobożnej wioski”. Ta wartość jest scharakteryzowana poprzez określone symbole, mierzone ilością kapliczek oraz krzyży zlokalizowanych przy machowskich drogach. Przydrożne kapliczki są jednocześnie miejscem kultu oraz integracji społeczności wioskowej. Wspomniana „pobożność” jest ponadto kultywowana poprzez wspólnotowe, jak stwierdza narrator, „procesje” związane z uczestnictwem machowiaków we mszy świętej w niedzielę, w kościele parafialnym w Miechocinie, „zawsze w niedzielę ludzi szli pieszo, pamiętam niektórzy boso. Później były rowery, albo konie z furmankami, to wszystko było takie kolorowe, urocze".

Podkreśla wartość działalności preferowanej przez mieszkańców Machowa, stanowiącej jednocześnie jeden z podstawowych elementów utrzymania, jakim była uprawa sadów owocowych. Wspomina ważną postać w dziejach tej wsi, pochodzącego z Machowa senatora Wojciecha Wiącka, który promował ten rodzaj działalności gospodarczej, rozpowszechniając rezultaty pracy machowiaków również poza granicami wsi. Jak wspomina, „te jabłka były rozsławione, [...] ludzie jeździli nawet do Krakowa, do Łodzi z tymi koszałkami czy z tymi skrzynkami, czy w torbach wieźli te jabłka”. Po przesiedleniu, w „nowych miejscach", machowiacy, jak wspomina narrator, dopingowali innych w celu podjęcia tego rodzaju działalności. Opowiada również, że mieszkańcy Machowa, mimo dużej aktywności związanej ze sferą rolniczą, angażowali się w działalność kulturalną. Wskazuje na ważna rolę, jaką w tym obszarze odegrała mieszkanka Machowa, pani Maria Kozłowa. W relacji narratora jest postrzegana jak swoista lokalna liderka, wyposażona w szerokie umiejętności artystyczne oraz organizatorskie, związane m.in. z uczestnictwem zarówno młodego, jak i starszego pokolenia mieszkańców Machowa w różnego rodzaju aktywnościach związanych ze sferą kulturalny. Instytucją ważną społecznie, na którą wskazuje narrator, była czteroklasowa szkoła podstawowa, prowadzona przez „miejscową" nauczycielką, panią Tęczową.

Funkcjonowanie Machowa zostało zakłócone w efekcie postępującej industrializacji. Sytuację tę określa narrator mianem „szoku”, jakiego doświadczyli przede wszystkim dorośli mieszkańcy Machowa. Doświadczenie „szoku” jest 
definiowane przez narratora w kategoriach: utraty dóbr materialnych („ludzie się dorobili”), niepewności związanej ze zmianą miejsca zamieszkania („iść w nieznane") oraz obawą dotyczącą akceptacji ze strony Innych (,jak przyjmą”). Jak wspomina, „przywiązaniem do ziemi” w sytuacji zmiany miejsca zamieszkania staje się tożsame z brakiem możliwości wpływu i jednocześnie kontrolowania własnej egzystencji.

Narrator wychowywał się w tradycyjnej rodzinie. Główne źródło utrzymania stanowiła uprawa ziemi. Ojciec i dziadek byli właścicielami kuźni. Praca kowala, jak stwierdza narrator, to ciężka praca, praca w pocie czoła. Tym bardziej „w tamtych czasach”, kiedy „wszystkie czynności należało wykonywać ręcznie”. Dodaje, iż „wszyscy jesteśmy kowalami swego życia”. Precyzyjność i poświecenie, jakie towarzyszyły ojcu w wykonywanej pracy, porównuje do pracy kapłana, „misjonarza w kuźni Pana Boga”. Mówi więc: „misjonarz jest postrzegany przez tubylców jak człowiek, który wszystko wie, wszystko ma, wszystko potrafi i nie można żyć inaczej, bo zawiedziemy ich oczekiwania". Przywieziona z Machowa podkowa ma dla narratora wartość sentymentalną, określą ją mianem herbu rodzinnego. Chociaż, jak podkreśla, on sam w jakimś stopniu tę tradycję przerwał. Nadaje jej zarówno wymiar symboliczny, jak i altruistyczny, ucieleśniający odpowiedzialność za własne wybory i decyzje (,podkowa to również but konia, a my wszyscy, idąc po tej ziemi, musimy zostawić jakiś widzialny znak dla przyszłości. Oby pozostał po nas dobry ślad").

W swojej opowieści, narrator kreuje postać ojca, jako osoby odpowiedzialnej za materialną część życia rodziny. Mama zajmowała się gospodarstwem domowym. Akcentuje umiejętności, jakie rodzice nabyli w związku z wykonywaniem codziennych czynności, które później, po przesiedleniu, zostały wykorzystane w nowym środowisku, przyczyniając się do raczej szybkiej adaptacji w nowym miejscu. Kompetencje, jakie osiągnął ojciec narratora (kowalstwo, mechanika), znalazły uznanie wśród miejscowej ludności. Osoba mamy, jawi się jako postać przede wszystkim przedsiębiorcza, dzięki pewnym cechom, jakie nabyła, żyjąc w Machowie („stamtąd to wynieśli”). Sens działań podejmowanych przez rodziców w rezultacie zostaje dostrzeżony i poprawnie wykorzystany przez nową społeczność. Miejscowi nie tylko dokonują zakupu produktów rolnych oferowanych przez rodziców narratora, korzystają również z możliwości „zarobkowania” u nich.

Narrator był najstarszym dzieckiem, miał dwie siostry. Uczęszczał do szkoły podstawowej w Machowie. Czas wolny od zajęć szkolnych spędzał podobnie 
jak jego rówieśnicy, przede wszystkim aktywnie. Godziny spędzane poza szkołą wypełniało się obowiązkami w zakresie pomocy w pracach polowych. Pozostałą ich część przeznaczano na spotkania z koleżeństwem. Ta forma czasu wolnego była również najczęściej organizowana w przestrzeni, gdyż, jak wspomina narrator, „dzieci nie siedziały w domu”. Kiedy rozpoczyna się proces przesiedlenia, zamieszkuje u babci, aby mógł ukończyć edukację w tamtym roku szkolnym.

Sytuacja związana z opuszczeniem Machowa nie wywołuje negatywnych wspomnień u narratora. Podkreśla, że zachodzące przeobrażenia społeczne wywoływały niepokój wśród dorosłych mieszkańców. Natomiast z jego perspektywy, jako dziecka, jawi się ono jako pewna podróż w nieznane, aczkolwiek nacechowana dziecięcą ciekawością poznania nowego, być może fascynującego miejsca. Mówi więc: „pamiętam, jak kilka razy jechałem na przyczepie z tyłu samochodu w jakiejś tam beczce, żeby tu przyjechać, zobaczyć, jak wygląda ten Zbydniów". W nowym środowisku, które postrzegane jest przez pryzmat pełnionej roli ucznia, jak podkreśla, zaistniała konieczność „zaklimatyzowania się". Jednakże wskazuje, że „przyjęcie było bardzo sympatyczne”, co zawdzięcza przede wszystkim autorytetowi dyrektorowi szkoły. Z jego opowieści wynika, że jest to pierwsze ważne zdarzenie związane z jego obecnością w nowym miejscu. Narrator doświadcza istotnego wsparcia, jakie zostało skierowane zarówno wobec jego osoby oraz dwóch jego kolegów: „pamiętam rozpoczęcie roku szkolnego, dyrektor tutaj przedstawił wszystkim, że są dzieci stamtąd [...] i tutaj będą rozpoczynać z nami rok szkolny [...] to tak było raźniej".

\section{Madagaskar}

Jak wspomina narrator, „w międzyczasie wpadła mi do rąk książka Arkadego Fidlera Madagaskar okrutny czarodziej i ja tę książkę przeczytałem, tą książką tak mnie oczarował ten Madagaskar, ta jedna książka i podjąłem decyzję". Z perspektywy lat nie jest w stanie jednoznacznie określić zarówno miejsca, w którym czytał książkę („,zy było to w seminarium, czy tu w domu”), okoliczności jej nabycia („nie wiem skąd ona się wzięła”), jak i dalszych jej losów (,ja teraz szukam tej książki i nie wiem gdzie ona mi zniknęła"). Narrator stwierdza, że jego powołanie narodziło się w Machowie. Zainteresowania przejawiające się w dzieciństwie zapowiadają przyszłego duchownego. Jak wspomina narrator, gromadził wokół siebie inne dzieci, którym głosił kazania: „przebierałem się w sukienki 
mamy i wychodząc na schody, na strych i stamtąd głosiłem [...] od Machowa do Nagnajowa i głosiłem im kazania. [...] niektóre nie bardzo chciały śpiewać i słuchać, ale chodzili za mną". Decyzja dotycząca wyboru stanu duchownego, jak wynika z opowieści narratora, była przemyślana i przede wszystkim samodzielna. Wskazuje na znaczącą rolę, autorytet oraz oczekiwania społeczne, jakie są kierowane wobec osób duchownych, w tym ówczesnego proboszcza parafii ${ }^{9}$, jednakże jak stwierdza, nie pamięta żadnych sugestii z jego strony. Pierwszymi osobami, które zostały oficjalnie poinformowane o zamiarze wyboru stanu duchownego, była mama oraz babcia (ze strony matki): „[...] pamiętam jak dziś to było tu w domu i wtedy mama była jeszcze przy maszynie coś tam szyła [...] babcia przyszła tutaj, a ja tak wtedy mówiłem, że mam zamiar i chcę pójść do seminarium". Kobiety nie wykazywały większego wsparcia na wieść o takim wyborze, ale również go nie negowały. Jak wynika z opowieści, mama przyjęła informację raczej spokojnie, aczkolwiek nie ustosunkowała się do niej. Jak wspomina narrator, „przestała szyć na maszynie i popatrzyła się na mnie, co ja opowiadam". Podobnie babcia, wskazywała jedynie na trud związany z obecnością w seminarium, podkreślając jednocześnie wagę obowiązujących praktyk. Jakkolwiek wiedza babci w tym zakresie była imponująca, nie przekreśliła jego aspiracji i wyborów. Konsekwentne dążenie do celu, determinacja nie budzą w tym momencie jakichkolwiek wątpliwości. Od czasu, gdy poinformował rodzinę o swoich życiowych zamiarach, rozpoczął konsekwentnie realizować swój plan. Aczkolwiek w początkowej fazie był on zorientowany na edukację, bez perspektywy związanej z rodzajem oraz miejscem działalności duszpasterskiej. W latach siedemdziesiątych, w przemyskim seminarium po raz pierwszy narrator spotkał się z misjonarzami. Jak wspomina: „To byli Polacy misjonarze, czasami siostry zakonne, zaczęli przywozić zdjęcia i opowiadania itd., itd., i to w jakiś sposób właśnie wpłynęło na moją decyzję, żeby być misjonarzem i wyjechać gdzieś do Afryki, do Afryki najpierw". Jego przyszłościowe dążenia zdecydowanie wykraczają poza europejską przestrzeń. Wola „zetknięcia się" z innym, wcześniej nieznanym i niedostępnym światem zaczyna go intrygować i pociągać. Staje się impulsem do podjęcia próby zmierzenia się z egzotycznym światem, chociaż miejsce pełnienia posługi nie jest jeszcze zidentyfikowane. Potrzeba

9 Machów należał do parafii Miechocin. Miechocin stanowi najstarszą część Tarnobrzega (obecnie jedno z osiedli). 
zaangażowania w pracę misyjną spotyka się z organizacyjnymi utrudnieniami, które u narratora wzbudzają pewne wątpliwości. Ostateczny kres wewnętrznym rozterkom nadaje wizyta księdza misjonarza pracującego w Indonezji (,,i właśnie to była ostateczna taka moja decyzja, ja też idę"). Fascynacja działalnością misyjną wynikała z określonych wyobrażeń. Z jednej strony była definiowana poprzez pragnienie „głoszenia dobrej nowiny", z drugiej zaś z dbałością o pomoc w zakresie organizacji codziennego życia. Narrator podkreślał, że jego wolą było aktywne uczestnictwo w życiu społecznym „tych ludzi”. Oczarowanie lekturą książki Arkadego Fidlera warunkuje podjęcie ostateczne decyzji o miejscu prowadzenia działalności misyjnej, jest przekonany o pełnieniu posługi na Madagaskarze („,byłem przekonany, podjąłem decyzje i nie było odwrotu, nikt mnie nie mógł przekonać"). Pragnienie, zapał aktywnego działania na rzecz ubogich afrykańskich społeczności napotyka na pewne ograniczenia. Zaistniałe okoliczności jedynie wzmacniają kierunek działań narratora. Jest silnie zdeterminowany, jednocześnie cechuje go odwaga i ryzyko nakierowane na osiągnięcie konkretnego celu. Transformacja zarówno charakteru, jak i miejsca pracy staje się inspirująca i zachęcająca do dalszych przedsięwzięć, które narrator nazywa przeznaczeniem. Stwierdza: „[...] jechałem z radością tam, do mojego przeznaczenia [...], już z samolotu widziałem tą czerwona wyspę [...] i już to jest ta ziemia obiecana z wyboru. [...] później jadąc z lotniska [...] poprzez te dzielnice, wtedy dopiero zobaczyłem te biedę. Odkryłem biedę, brud itd. I to budownictwo i to wszystko. Zupełnie inny świat. [...] teren, który wymaga po prostu pracy i poświęcenia. [...] szybko się zaaklimatyzowałem także odkryłem świat, do którego byłem przeznaczony". Narrator przyjeżdża na Madagaskar z pewnymi ofertami. Jego wolą jest prowadzenie działalności duszpasterskiej oraz podjęcie starań celem aktywizacji ludności, zwłaszcza mieszkającej w buszu. Nowa przestrzeń aranżuje pole działania, kreując jednocześnie jego historię życia. Przekonanie o słuszności realizacji siebie, w relacji do nowej przestrzeni, nie ma charakteru procesualnego. Zarówno w wymiarze indywidualnym, jak i w kontekście przynależności do wspólnoty obdarzył je zaufaniem. Jest ona być może „niedookreślona”, ale posiadająca potencjał. Jak stwierdza Yi-Fu Tuan, uczłowieczona staje się miej$\mathrm{scem}^{10}$. Umiejscowienie się narratora w przestrzeni, która mogłaby wydawać

10 Yi-Fu Tuan, Przestrzeń i miejsce, przeł. A. Morawińska, Warszawa 1987, s. 75. 
się niedostępna i nieprzewidywalna, nastąpiło dość szybko. Stanowiła dystynktywny byt intencjonalny, stając się jednocześnie terenem wielu zdarzeń, logicznego działania i przede wszystkim relacji z Innymi, w konsekwencji konsolidując „bycie w świecie" ${ }^{\prime 11}$.

\section{Podsumowanie}

W swojej opowieści narrator zwraca uwagę na dwa ważne miejsca w jego biografii, miejsce pochodzenia oraz miejsce pełnienia posługi misjonarskiej. Stają się one podstawą, na której kształtuje swoją tożsamość oraz realizuje swoją życiową rolę. Konstruuje własną rzeczywistość zarówno w wymiarze indywidualnym, jak i społecznym w oparciu o doświadczenie miejsca, które pozwala mu uzyskać samoidentyfikację. Miejsce zamieszkania stanowi fundament, na których dochodzi do istotnych procesów socjalizacyjnych. Aspekt edukacyjny jest obecny w grupach pierwotnych narratora. Osiąga w nich kompetencje oraz motywacje do działania. W szerszym wymiarze przyswaja środowiskowe wzorce niezbędne do społecznej partycypacji i integracji. W refleksji o miejscu pochodzenia w opowieści narratora można dostrzec również aspekt indywidualny i społeczny. Przemiany, jakie dokonały się w Machowie, są pozytywnie postrzegane przez narratora. Jak sam stwierdza, „[...] uważam, że jest dla dobra ojczyzny, bo mimo wszystko ta kopalnia siarki była dobra dla ojczyzny i społeczeństwa lokalnego. Teraz ten dół machowski został zalany i będzie służył dobru innemu znów, w tym wydaniu rekreacyjno-wypoczynkowy". W zarysie środowiskowym podkreśla wyjątkowość miejsca, na które składały się szczególne więzi łączące jej mieszkańców, respekt w przestrzeganiu obowiązujących wzorów życia oraz czynniki scalające jednostkę z przyrodą i kulturą. Akcentuje rolę znaczących Innych w jego życiu, wskazując przede wszystkim na rodziców

11 Martin Heidegger akcentuje związek miejsca z jestestwem. Bycie (jestestwo) bez miejsca nie jest możliwe. M. Heidegger, Bycie i czas, przeł. B. Baran, Warszawa, 1994, s. 18. Heidegger sformułował koncepcje miejsca odmienną od koncepcji Arystotelesowskiej. Wedle jej założeń miejsce jest od samego początku wypełnione jakościowo przez obecną w nim rzecz. Jego istotę stanowi relacyjność, a nie absolutność. Jest konstytuowane w ludzkiej egzystencji i ze względu na tę egzystencje. Por. H. Buczyńska-Garewicz, Miejsca, strony, okolice. Przyczynek do fenomenologii przestrzeni, Kraków 2006, s. $25-27$. 
oraz osoby uznane za ważne przez lokalną społeczność. Podkreśla istotną rolę lokalnych autorytetów w życiu mieszkańców wsi. Machów staje się zatem miejscem, którego atmosfera uwidacznia się w sferze wartości, wzorców postępowania opartych na współpracy i współdziałaniu z innymi ludźmi. Jest miejscem kształtowaniu określonego porządku, o charakterze społecznym i kulturowym. Wyposaża narratora w umiejętność budowania relacji, które dają poczucie zakorzenienia, bezpieczeństwa, ale jednocześnie otwartości. Nabyte umiejętności i kompetencje posłużyły aktywnej działalności misyjnej. Madagaskar to przestrzeń, którą w sposób dynamiczny „uczłowiecza”. Miejsce, w którym realizuje swoje plany biograficzne. Motywacja ma przede wszystkim charakter aksjologiczny ${ }^{12}$. Jak wynika z opowieści narratora, jest nią służba na rzecz społeczności malgaskiej, nazywa ją „czekoladowym światem”.

Streszczenie: Celem artykułu jest ukazanie znaczenia miejsca w życiu narratora. Podstawą analizy jest narracja, jakiej wysłuchałam w związku z prowadzeniem badań biograficznych wśród mieszkańców Machowa. Na terenie tej społeczności lokalnej w latach pięćdziesiątych ubiegłego stulecia odkryto złoża siarki i podjęto decyzję o budowie kopalni. W konsekwencji mieszkańcy Machowa zostali przesiedleni. Badania z osobami przesiedlonymi przeprowadziłam na podstawie wywiadu narracyjnego. Mój narrator, wraz z rodzicami i rodzeństwem opuścił Machów w roku 1960. Obecnie pracuje jako misjonarz na Madagaskarze.

Słowa kluczowe: miejsce, badania biograficzne, narracja, społeczność lokalna.

\section{Bibliografia}

Buczyńska-Garewicz H., Miejsca, strony, okolice. Przyczynek do fenomenologii przestrzeni, Kraków 2006.

Heidegger M., Bycie i czas, przeł. B. Baran, Warszawa, 1994.

12 Galia Chimiak, na podstawie własnych badań oraz typologii dostępnych w literaturze, dokonała typologii motywacji w zakresie działań w sferze publicznej. Wyróżniła następujące rodzaje motywacji: wewnętrzna, aksjologiczna, zewnętrzna, racjonalna, altruistyczna, związana ze sprawowaniem władzy, zorientowana na zmianę, mająca na celu realizację wizji, czasu wolnego, E. Kurantowicz, O uczących się społecznościach. Wybrane praktyki edukacyjne ludzi dorosłych, Wrocław 2007, s. 105. 
Kurantowicz E., O uczących się społecznościach. Wybrane praktyki edukacyjne ludzi dorosłych, Wrocław 2007.

Ladson-Billings G., Foreword, The Foreign self. True Telling as Educational Inquiry, red. F. Tochon, Madison, WI, 2002.

Melchior M., Społeczna tożsamość jednostki, Warszawa 1990.

Mendel M., Pedagogika miejsca i animacja na miejsce wrażliwa, w: Pedagogika miejsca, red. M. Mendel, Wrocław 2006.

Ricoeur P., Egzystencja i hermeneutyka: rozprawy o metodzie, przeł. E. Bieńkowska i in., Warszawa 1975.

Szacki J., Historia myśli socjologicznej, Warszawa 2012.

Szacki J., Tonnies Ferdynand, w: Encyklopedia socjologii, Warszawa 2002.

Szczepański M. S., Ślęzak-Tazbir W., Niegościnne przestrzenie. Getta społeczne i przestrzenne $w$ starym regionie przemysłowym, w: Percepcja współczesnej przestrzeni miejskiej, red. M. Madurowicz, Warszawa 2007.

Theiss W., Mała ojczyzna. Kultura, Edukacja, Rozwój lokalny, Warszawa 2001.

Yi-Fu Tuan, Przestrzeń i miejsce, przeł. A. Morawińska, Warszawa 1987. 